\title{
Сучасні підходи до діагностики та лікування IgG4-асоційованої аневризми черевного відділу аорти
}

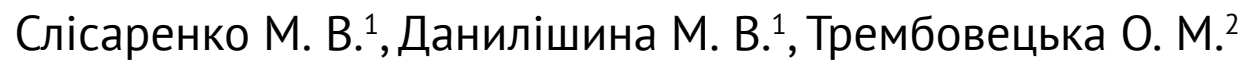 \\ ${ }^{1}$ Національний медичний університет імені О. О. Богомольця \\ ${ }^{2}$ ДУ «Національний інститут серцево-судинної хірургії імені М. М. Амосова НАМН» (Київ)
}

\begin{abstract}
IgG4-асоційовані захворювання - гетерогенна за ураженням органів група захворювань, що проявляються підвищеним вмістом IgG4 у плазмі крові та морфологічно характеризуються звивистим фіброзом, дифузною лімфоплазмоцитарною інфільтрацією з наявністю $\mathrm{IgG4-позитивних} \mathrm{плазмоцитів,} \mathrm{облітеруючим} \mathrm{флебітом.}$ Одним із проявів IgG4-асоційованих захворювань з боку судин є запальна аневризма абдомінальної аорти (ААА), Розвиток специфічних морфологічних змін, а також доведену ефективність імуносупресивної терапії слід враховувати у підходах до діагностики та лікувальної тактики. Проте на сьогодні у проблемі IgG4асоційованих захворювань залишається багато відкритих питань, що потребують глибокого вивчення.
\end{abstract}

Мета роботи - висвітлити необхідність виділення $\mathrm{IgG4-асоційованої} \mathrm{аневризми} \mathrm{черевного} \mathrm{відділу} \mathrm{аорти}$ як окремої нозологічної одиниці, наголосити на ролі морфологічного дослідження як основи для подальшого вивчення цієї проблеми та розробки чітких діагностичних критеріїв і алгоритмів лікування.

Матеріали і методи: аналіз даних наукових праць, що висвітлюють сучасні підходи до розуміння етіології, патогенезу, диференціальної діагностики та тактики лікування IgG4-асоційованої AAA.

Результати та обговорення. За результатами проведеного огляду літератури встановлено, що абдомінальний відділ аорти може залучатись до патологічного процесу при IgG4-асоційованих захворюваннях як у складі системної патології, так і у вигляді окремих нозологічних одиниць. Оцінка біопсійного матеріалу із застосуванням імуногістохімічного дослідження у випадку запальної ААА відіграє ключову роль у встановленні діагнозу та визначенні подальшої тактики ведення пацієнта, одним з напрямів якої є застосування глюкокортикостероїдів для покращення перебігу післяопераційного періоду.

Висновки. Попри відсутність чітких діагностичних критеріїв та алгоритмів лікування IgG4-асоційованої AAA, визначальними у веденні пацієнтів та створенні статистичної платформи для подальших наукових досліджень є результати патогістологічного дослідження операційного матеріалу з використанням специфічних імуногістохімічних реакцій.

Ключові слова: IgG4-асоційовані захворювання, запальна аневризма аорти, IgG4-асоційована аневризма абдомінального відділу аорти, діагностичні критерії, патогістологічне дослідження, імуногістохімічні реакиії, диференціальна діагностика з інфікованою аневризмою.

IgG4-асоційовані захворювання - гетерогенна група захворювань, що характеризуються розвитком хронічного запального процесу, підвищеним рівнем IgG4 у плазмі крові, лімфоплазмоцитарною інфільтрацією, зокрема IgG4-позитивними плазмоцитами, розвитком фіброзу та облітеруючого флебіту в уражених тканинах. У структурі даних захворювань описано ураження слинних і сльозових залоз, підшлункової залози, легень, щитовидної залози, нирок, лімфатичних вузлів, клітковини ретроорбітального та заочеревинного простору [1]. Протягом останньої часу зареєстровані випадки виявлення аналогічних патологічних змін практично в усіх органах.

Вперше описання даної патології у вигляді запальної аневризми черевної аорти було здійснено в 2008 році, хоча подібна патогістологічна картина виявлялася і раніше [2]. В подальших дослідженнях судинної патології описано також коронарний артеріїт, запальну аневризму грудної частини аорти, периаортит та периартеріїт, пов'язаний із ретроперитонеальним фіброзом. Не виключена роль IgG4-асоційованого ураження у випадках розшаровуючої аневризми аорти та раптової серцевої смерті.

IgG4-асоційовані ураження судин, зокрема й черевного відділу аорти, поділяють на дві групи: первинні та вторинні (ті, шо виникають унаслідок поширення патологічного процесу із сусідніх ділянок). Зустрічається одночасний розвиток ідентичних патологічних змін у кількох органах, що наштовхує на думку про системність процесу. Цей факт, а також доведену ефективність імуносупресивної терапії слід ураховувати у підходах до діагностики та лікувальної тактики у пацієнтів із даною судинною патологією.

Мета роботи - висвітлити сучасні тенденції у підходах до етіології, морфологічних проявів, критеріїв діа- 
гностики та принципів лікування IgG4-асоційованих захворювань черевного відділу аорти; довести доцільність виокремлення даних форм патології аорти як самостійних нозологічних одиниць, а також їх урахування при проведенні диференційної діагностики.

Епідеміологія та класифікація. Враховуючи, що переважна більшість випадків даних захворювань діагностується і вивчається японськими дослідниками, слід припустити, шо в решті популяції захворюваність може коливатися в невизначених межах. У зв'язку з низьким рівнем настороженості щодо даної патології в процесі діагностики, справжня ії̈ частка може бути значно більшою. ААА діагностується у 4-10\% населення старше 60 років і зустрічається частіше в чоловіків, ніж у жінок. 3 усіх випадків AАA на запальну аневризму припадає 5-10\%, переважно з ураженням в осіб молодшого віку [3].

Класифікуючи IgG4-асоційовані захворювання, що охоплюють ретроперитонеальний простір та аорту, дослідники виділяють такі їх форми:

- IgG4-асоційований ретроперитонеальний фіброз;

- запальна аневризма абдомінальної аорти;

- комбіноване ураження ретроперитонеального простору та аорти.

Терміни «IgG4-асоційований ретроперитонеальний фіброз» та «IgG4-асоційований аортит» вживаються як синоніми до вказаних вище нозологічних одиниць [4]. Проте в літературі термін «запальна аневризма абдомінальної аорти» часто використовується в контексті не лише IgG4-асоційованих захворювань, а й уражень із підтвердженою бактеріальною етіологією (так звана «інфікована аневризма»), а також випадків, що не відповідають діагностичним критеріям IgG4асоційованих захворювань [5].

Етіологія та патогенез IgG4-асоційованих захворювань досі залишаються остаточно не з'ясованими. IgG4 в нормі не перевищують 5\% загального пулу $\mathrm{IgG}$, хоча при алергічних процесах їх частка може збільшуватись аж до 80\%. Як і інші підтипи, ці імуноглобуліни складаються з двох важких і двох легких ланцюгів, однак дисульфідні зв'язки між ними нестійкі. IgG4 має низьку здатність активувати комплемент і утворювати імунні комплекси, тому припускають, що його ефект носить протизапальний характер. Прямий зв'язок між інфільтрацією тканини IgG4-позитивними плазмоцитами та розвитком у ній фіброзних змін не простежується. Вважають, що під впливом певного тригерного фактору, можливо, вірусної інфекції, спричинена імунна відповідь проявляється лімфоплазмоцитарною інфільтрацією 3 вивільненням цитокінів, що активізують фібробласти, а наявні IgG4-позитивні плазмоцити виконують, скоріше, гальмівну функцію. Розвиток імунної реакції за Th2-типом пояснює підвищений рівень IgG4 i в плазмі крові [6].
Клінічна картина та діагностичні критерії. На відміну від атеросклеротичної аневризми, IgG4-асоційована аневризма черевного відділу аорти рідко проявляється болем у спині або животі, проте при пальпації в обох випадках може виявлятись об'ємне утворення. У таких пацієнтів частіше спостерігаються медикаментозні алергії, супутні аутоімунні захворювання, серед неспецифічних змін у лабораторних показниках - підвищений рівень IgE, наявність антинуклеарних антитіл [8].

Приблизно у 85\% пацієнтів одночасно наявний щонайменше один позасудинний прояв IgG4асоційованих захворювань [7].

Діагностичні критерії остаточно не сформульовані і варіюють залежно від ураженого органа, проте серед них у 2011 році виділили такі основні ознаки:

- наявність клінічних ознак дифузного чи вогнищевого набряку або формування певних мас в одному чи кількох органах;

- підвищення рівня IgG4 у плазмі крові вище 135 мг/дл;

- співвідношення $\operatorname{IgG} 4+/ \mathrm{IgG}+$ плазматичних клітин більше $40 \%$, а також виявлення не менше 10 IgG4+плазмоцитів при великому збільшенні в зразку біопсії. Достовірним діагноз можна вважати за наявності всіх трьох критеріїв, ймовірним - першого і третього, а можливим - першого та другого.

Слід наголосити, що на сучасному етапі досліджень встановлено підвищення рівня IgG4 в плазмі крові і при інших захворюваннях, наприклад, злоякісних новоутвореннях, атопічному дерматиті, бронхіальній астмі, хворобі Кастельмана тощо, тому для верифікації діагнозу необхідні специфічні патогістологічні ознаки [9].

Патогістологічна картина. При патогістологічному дослідженні операційного матеріалу виявляють потовщення адвентиції, проліферацію веретеноподібних фібробластів, значний розвиток колагенових волокон, що формує звивистий патерн. Наявна помірно або значно виражена запальна інфільтрація у вигляді дифузних кластерів плазмоцитів і лімфоцитів (рис. 1). Дані зміни дифузно представлені в адвентиції та вогнищево в медії. На відміну від інших форм IgG4-асоційованих захворювань, облітеруючий флебіт не є типовою знахідкою. Іноді виявляють лімфоїдні фолікули, поодинокі еозинофіли та нейтрофіли. При фарбуванні за Ван Гізоном визначається дублікація та розриви зовнішньої еластичної пластинки як ознака формування аневризми. Як і при атеросклеротичній аневризмі аорти, може спостерігатися проліферація фібробластів і формування атеросклеротичних бляшок в інтимі. Імуногістохімічне дослідження виявляе позитивну реакцію на віментин, SMA (smooth muscle antigen) та IgG4 у $100 \%$ випадків (рис. 2а, б). Приблизно у $70 \%$ випадків позитивна також реакція на CD34.

У разі вторинного залучення стінки аорти до патологічного процесу при ретроперитонеальному фіброзі 

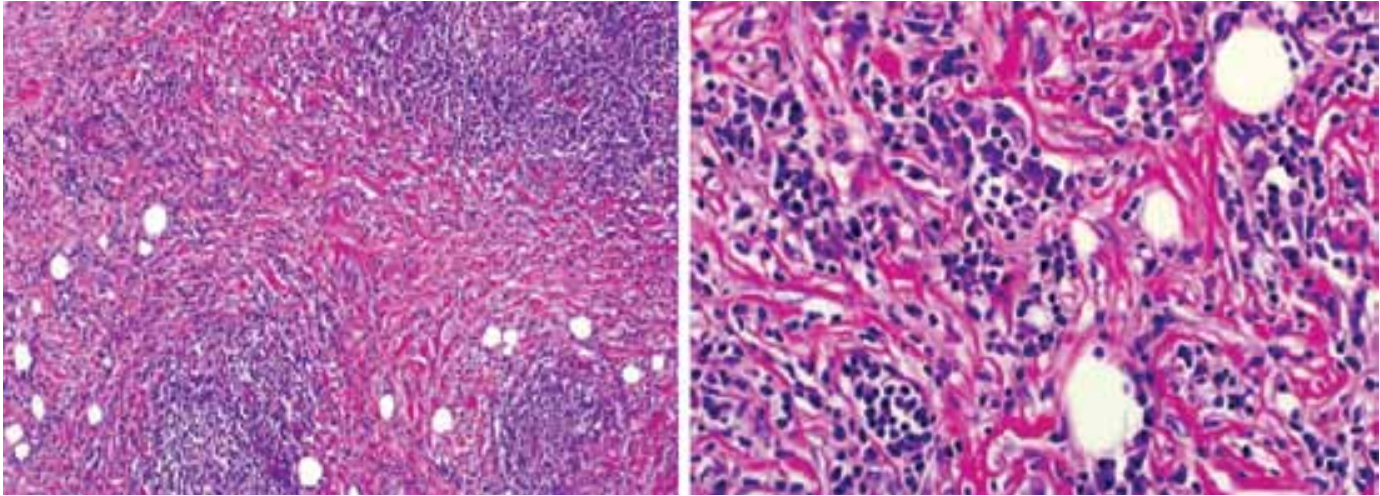

Pис. 1. (H\&E; 100×, 400×). Наявна проліферація фібробластів, звивистий фіброз, помірно виражена лімфоплазмоцитарна інфільтрація [4]
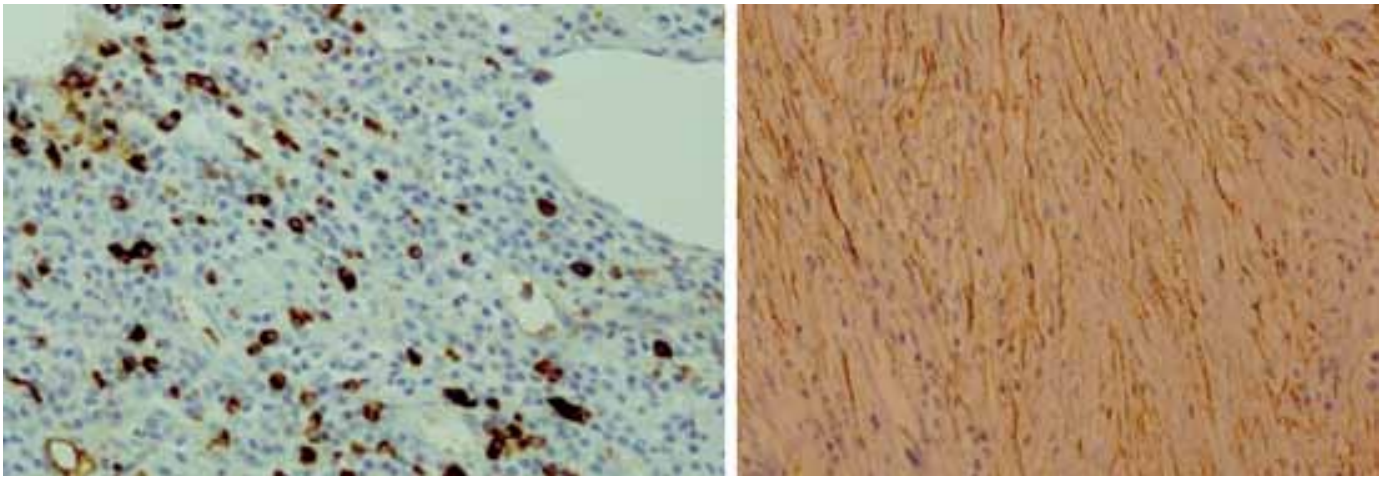

Рис. 2. Імуногістохімічне дослідження: а) позитивна реакція на IgG4; б) позитивна реакція на актин (SMA) [4]

ідентична мікроскопічна картина спостерігається в прилеглій клітковині з поступовим переходом на адвентиційну оболонку [4, 7].

Ключові принципи лікування та диференціальної діагностики. Враховуючи ризик виникнення такого загрозливого для життя ускладнення, як розрив аневризми, на першому плані беззаперечно залишається хірургічний підхід до лікування. У певних випадках у якості складової комплексного лікування можливе застосування глюкокортикостероїдів як монотерапії або в поєднанні з ритуксимабом. Для моніторингу ефективності терапії використовують ОФЕКТ з 18F-флюородезоксиглюкозою, що дозволяє оцінити межі поширеності запального процесу в динаміці [10].

Слід розглянути доцільність призначення глюкокортикостероїдів у післяопераційному періоді у зв'язку з високим ризиком розвитку дисекції аорти у пацієнтів із запальною ААA [11]. Проте застосування імуносупресивної терапії виправдане лише у випадку достовірного діагнозу IgG4-асоційованого ураження аорти і вкрай небезпечне в разі інфікованої аневризми. Віддиференціювати інфіковану аневризму абдомінальної аорти допомагають такі клінічні ознаки:

- більш виражений больовий синдром;

- лейкоцитоз із зсувом формули вліво;

- позитивна гемокультура (найчастіше збудниками є Salmonella, Staphylococcus, Campylobacter i Streptococcus species).

Існують певні відмінності у формі самої аневризми: інфікована аневризма на КТ частіше мішкоподібна, a IgG4-асоційована має форму веретена. Для інфікованої аневризми також характерне швидке збільшення діаметру і вищий ризик розриву, тому невід'ємною складовою лікування є інтенсивна антибіотикотерапія в перед- і післяопераційному періоді. Патогістологічні відмінності полягають у відсутності патерну звивистого фіброзу та IgG4+- плазматичних клітин у запальному інфільтраті. Рівень IgG4 в плазмі крові може незначно підвищуватись і при інфікованій аневризмі, тому його оцінка в диференціальній діагностиці відіграє другорядну роль.

Диференціальна діагностика 3 атеросклеротичною аневризмою базується на критеріях встановлення діагнозу IgG4-асоційованих захворювань і даних лабора- 
торно-інструментальних методів досліджень. Патогістологічне дослідження операційного матеріалу також має на меті виключити неопластичний процес [5].

Результати та обговорення. Отже, за результатами проведеного огляду літератури встановлено, що абдомінальний відділ аорти може залучатись до патологічного процесу при IgG4-асоційованих захворюваннях як у складі системної патології, так і у вигляді окремих нозологічних одиниць, серед яких на сьогодні виділено ретроперитонеальний фіброз, запальну аневризму черевної аорти та комбіноване ураження. Попри відсутність чіткого розуміння етіології та патогенезу цієї групи захворювань, вважають, що в основі лежить аутоімунний запальний процес, тригерним фактором якого, можливо, є вірусна інфекція. Діагностика грунтується на співставленні клінічних даних з виявленим підвищеним титром IgG4 у плазмі крові та специфічною патогістологічною картиною. Оцінка біопсійного матеріалу із застосуванням імуногістохімічного дослідження у випадку запальної аневризми аорти відіграє ключову роль у постановці діагнозу і визначенні подальшої тактики ведення пацієнта, одним з напрямів якої є застосування глюкокортикостероїдів для покращення перебігу післяопераційного періоду.

Висновки. Відносно короткий проміжок часу з моменту відкриття IgG4-асоційованих захворювань, нестача великомасштабних досліджень, відсутність чітких діагностичних критеріїв та алгоритмів лікування стосовно IgG4-асоційованої патології аорти в цілому і аневризми абдомінальної аорти зокрема зумовлюють необхідність подальшого глибокого вивчення цієї проблеми. Очевидна також роль патогістологічного дослідження операційного матеріалу з використанням специфічних імуногістохімічних реакцій як підгрунтя для встановлення діагнозу IgG4-асоційованої аневризми та створення статистичної платформи для формулювання певних діагностичних критеріїв і класифікацій у майбутньому.

\section{Література}

1. Yamamoto M., Hashimoto M.,Takahashi H. IgG4 Disease // Journal of Neuro-Ophthalmology. - 2014. Vol. 34. - P. 393-399. - Режим доступу : http://mobile. journals.lww.com/jneuroophthalmology/_layouts/15/ oaks.journals.mobile/default.aspx
2. Inflammatory abdominal aortic aneurysm: close relationship to IgG4-related peri-aortitis / Kasashima S., Zen Y., Kawashima A. et al. // Am J Surg Pathol. - 2008. Vol. 32. - P. 197-204. - Режим доступу : http://journals. lww.com/ajsp/pages/articleviewer.aspx?year $=2008 \&$ issue $=02000 \&$ article $=00003 \&$ type $=$ abstract

3. Hellmann D. B., Grand D. J. Inflammatory abdominal aortic aneurysm // JAMA. - 2007. - Vol. 297. - P. 395400. - Режим доступу : http://jamanetwork.com/ journals/jama/article-abstract/205226

4. Inflammatory aortic aneurysm: possible manifestation of IgG4-related sclerosing disease / Raparia K., Molina C., Quiroga-Garza G. // Int J Clin Exp Pathol. - 2013. Vol. 6 (3). - P. 469-75. - Режим доступу : https://www. ncbi.nlm.nih.gov/pmc/articles/PMC3563203

5. Infected aortic aneurysm and inflammatory aortic aneurysm -in search of an optimal differential diagnosis / Nobukazu I., Koichi S., Masatoshi M. // Journal of Cardiology. - 2012. - Vol. 59. - P. 123-131. - Режим доступу : http://www.journal-of-cardiology.com/article/ S0914-5087(11)00222-X/abstract

6. IgG4-related disease: A concise review of the current literature / Ardila-Suarez O., Abril A., Gymez-Puerta J. // Reumatol Clin. - 2016. - Vol. 18. - Режим доступу : http://www.reumatologiaclinica.org

7. Perugino A. Large vessel involvement by IgG4-related disease // Medicine (Baltimore). - 2016. - Vol. 95 (28). e33-44. - Режим доступу : https://www.ncbi.nlm.nih. gov/pmc/journals/2786

8. A new clinicopathological entity of IgG4-related inflammatory abdominal aortic aneurysm / Kasashima S. 1., Zen Y., Kawashima A. // J Vasc Surg. - 2009. - Vol. 49 (5). - P. 1264-71.

9. Kazuichi O., Hisanori U. Are Classification Criteria for IgG4-RD Now Possible? The Concept of IgG4-Related Disease and Proposal of Comprehensive Diagnostic Criteria in Japan // International Journal of Rheumatology. 2012. - Vol. 2012. - Режим доступу : http://dx.doi. org/10.1155/2012/357071

10. Vasaitis L. IgG4-related disease: A relatively new concept for clinicians // Eur J Intern Med. - 2016. - Режим доступу : http://www.ejinme.com/article/S0953-6205(15)00329-5/ fulltext

11. Surgical treatment of inflammatory abdominal aortic aneurysms: outcome and predictors analysis / Nuellari E., Prifti E., Esposito G. // Med Arch. - 2014. - Vol. 68 (4). Р. 244-248. - Режим доступу : http://www.scopemed. org/?jid=10

\title{
Modern tactic according to diagnostic and treatment of IgG4-associated abdominal aorta aneurysm
}

\author{
Slisarenko M. V. ${ }^{1}$, Danylishyna M. V. ${ }^{1}$, Trembovetska O. M. ${ }^{2}$ \\ ${ }^{1}$ Bogomolets National Medical University \\ ${ }^{2}$ National M. M. Amosov Institute of Cardiovascular Surgery National Academy of Medical Sciences of Ukraine
}

IgG4-related diseases are geterogenic in organs involvement group of disoders characterized by elevated serum IgG4 level and morphologicaly presented with diffuse lymphoplasmacytic infiltration including IgG4-positive plasma cells, irregular fibrosis, and obliterative phlebitis. One of the manifestations of vascular IgG4-related diseases is an inflammatory 
abdominal aortic aneurysm (AAA). The development of specific morphological changes and proven effectiveness of immunosuppressive therapy should be considered in approaches to diagnosis and treatment strategy. However, today there are many questions in problem of IgG4-related diseases requiring their in-depth study.

Objective: to highlight the necessity to define the IgG4-associated abdominal aorta aneurysm as a separate nosological unit and to emphasize the role of histopathological studies as a basis for further researches and elaboration of clear diagnostic criteria and treatment algorithms.

Materials and methods: analysis of scientific data highlighting up-to-date approaches to understanding of etiology, pathogenesis, differential diagnosis and treatment strategy in case of IgG4-associated AAA.

Results and discussion. According to results of the literature review in case of IgG4-associated diseases the abdominal aorta may be involved in the pathological process as a part of systemic disease, as well as a separate nosological unit. Evaluation of biopsy material using immunohistochemical reactions in the case of inflammatory AAA plays a key role in determining the diagnosis and patients management one of the lines of which is administration of corticosteroids to improve the postoperative period.

Conclusions. Despite the lack of clear diagnostic criteria and treatment algorithms for IgG4-associated AAA, the results of histopathological study of biopsy specimens using specific immunohistochemical reactions play decisive role in the approach to patients management and creating statistical platform for further researches.

Key words: IgG4-related diseases, inflammatory aortic aneurysm, IgG4-associated aneurysm of abdominal aorta, diagnostic criteria, histopathological studies, immunohistochemical reactions, differential diagnosis with infected aneurysm.

\title{
Современные подходы к диагностике и лечению IgG4-ассоциированной аневризмы брюшного отдела аорты
}

\author{
Слисаренко М. В. ${ }^{1}$, Данилишина М. В. ${ }^{1}$, Трембовецкая Е. М. ${ }^{2}$ \\ ${ }^{1}$ Национальный медицинский университет имени А. А. Богомольца \\ 2 ГУ «Национальный институт сердечно-сосудистой хирургии имени Н. М. Амосова НАМН» (Киев)
}

IgG4-ассоциированные заболевания - гетерогенная по поражению органов группа заболеваний, проявляющихся повышенным содержанием IgG4 в плазме крови и морфологически характеризирующихся извилистым фиброзом, диффузной лимфоплазмоцитарной инфильтрацией с наличием IgG4-положительных плазмоцитов, облитерирующим флебитом. Одним из проявлений IgG4-ассоциированных заболеваний со стороны сосудов является воспалительная аневризма абдоминальной аорты (AАA). Развитие специфических морфологических изменений, а также доказанную эффективность иммуносупрессивной терапии следует учитывать в подходах к диагностике и лечебной тактике. Однако на сегодня в проблеме IgG4-ассоциированных заболеваний остается много открытых вопросов, требующих глубокого изучения.

Цель работы - доказать необходимость выделения IgG4-ассоциированной аневризмы брюшного отдела аорты как отдельной нозологической единицы, подчеркнуть роль патогистологического исследования как основы для дальнейшего изучения этой проблемы и разработки четких диагностических критериев и алгоритмов лечения.

Материалы и методы: анализ научных данных, освещающих современные подходы к пониманию этиопатогенеза, дифдиагностики и тактики лечения IgG4-ассоциированной AAA.

Результаты и обсуждение. По результатам проведенного обзора литературы установлено, что абдоминальный отдел аорты может вовлекаться в патологический процесса при IgG4-ассоциированных заболеваниях как в составе системной патологии, так и в виде отдельных нозологических единиц. Оценка биопсийного материала с применением иммуногистохимического исследования в случае воспалительной ААА играет ключевую роль в постановке диагноза и определении дальнейшей тактики ведения пациента, одним из направлений которой является применение глюкокортикостероидов для улучшения течения послеоперационного периода.

Выводы. Несмотря на отсутствие четких диагностических критериев и алгоритмов лечения IgG4ассоциированной AАA, определяющими в ведении пациентов и создании статистической платформы для дальнейших научных исследований являются результаты патогистологического исследования операционного материала с использованием специфических иммуногистохимических реакций.

Ключевые слова: IgG4-ассоциированные заболевания, воспалительная аневризма аорты, IgG4-ассоциированная аневризма абдоминального отдела аорты, диагностические критерии, патогистологическое исследование, иммуногистохимические реакции, дифдиагностика с инфицированной аневризмой. 